\title{
USPOREDBA SUSTAVA ZA UPRAVLJANJE VOZNIM PARKOM ${ }^{4}$
}

\section{SAŽETAK}

Upotreba sustava za upravljanje voznim parkom značajno olakšava i unaprjeđuje organizaciju rada i samo poslovanje suvremenih transportnih poduzeća. Takvi sustavi omogućuju automatizaciju i optimizaciju poslovnih procesa povezujući sve segmente poslovanja (disponiranje, nabavu, komunikaciju, navigaciju, računovodstvo i financije) u učinkovitu cjelinu koristeći pritom suvremena tehnološka rješenja kao što su satelitski sustav navigacije, mobilnu tehnologiju, bežičnu komunikaciju i prijenos podataka, računarstvo u oblaku te telemetriju (sonde i senzori u vozilima, uređaji za udaljenu dijagnostiku). Sustavi za upravljanje voznim parkom u svakom trenutku mogu odrediti položaj vozila u realnom vremenu, obaviti daljinsku kontrolu vozila i vršiti razna mjerenja, bilježiti i optimizirati rute, pratiti radno vrijeme vozača, pratiti troškove vozila i cijelog voznog parka te arhivirati prikupljene podatake radi njihovog naknadnog pretraživanja, analiziranja i stvaranja različitih izvještaja. Rad donosi komparativnu analizu triju takvih sustava (Mobilisis, CVS Mobile i My GPS) koja proizlazi iz njihovog stvarnog korištenja u transportnom poduzeću. Aplikacije se analiziraju i uspoređuju s obzirom na mogućnosti prilagodbe sučelja, načina praćenja vozila, generiranja izvještaja, praćenje i kontrolu potrošnje goriva i ostalih troškova, izradu radnih naloga i putnih naloga te dostupnih oblika komunikacije između vozača i disponenata. Utvrđeno je da sustav Mobilisis daje najobuhvatnije rješenje, iako najskuplje, sve potrebne funkcionalnosti ima My GPS po znatno nižoj cijeni, a nedostatak CVS Mobile je u nemogućnosti izrade putnih naloga.

Ključne riječi: nadzor vozila, navigacija, upravljanje troškovima, putni nalozi, e-poslovanje

\section{UVOD}

Problemsko područje ovog rada predstavljaju sustavi za upravljanje voznim parkom, tzv. fleet management sustavi koji postaju važan dio poduzeća s flotom službenih i gospodarskih vozila. Procjenjuje se da će do 2020. godine samo u Sjevernoj Americi biti instalirano 12,7 milijuna sustava za upravljanje voznim parkom koji će nadzirati oko 180 milijuna komercijalnih vozila ili $90 \%$ cjelokupnog tržišta (Statista, 2016; Newman, 2016). U Europi bi do 2021. godine trebalo

\footnotetext{
BS in Ecomics, Transporti Runko d. o. o., Marišće 46b, Pićan, Hrvatska. E-mail: barbara.skabic@gmail.com

Dr. sc., v. pred., Veleučilište u Rijeci, Vukovarska 58, 51000 Rijeka, Hrvatska.E-mail: elena@veleri.hr

3 Mr. sc., v. pred., Veleučilište u Rijeci, Vukovarska 58, 51000 Rijeka, Hrvatska.E-mail: jasminka.tomljanovic@veleri.hr

4 Datum primitka rada: 15. 1. 2018.; datum prihvaćanja rada: 1. 3. 2018.
} 
biti instalirano 14,1 milijuna takvih sustava, a najveća stopa njihova korištenja je u Njemačkoj (Fagerberg, 2017). Cilj rada je istražiti funkcioniranje sustava za upravljanje voznim parkom te utvrditi efekte njihove primjene u poslovanju poduzeća. Zadatak je analizirati tri sustava za upravljanje voznim parkom te na primjeru konkretnog transportnog poduzeća objasniti mogućnosti upravljanja poslovnim procesima i troškovima. Komparativna analiza triju sustava za upravljanje voznim parkom (Mobilisis, My GPS i CVS Mobile) proizlazi iz njihove svakodnevne uporabe u transportnom poduzeću. Radna hipoteza glasi: investiranje u sustav za upravljanje voznim parkom unaprjeđuje poslovanje i smanjuje troškove transportnog poduzeća.

\section{SUSTAVI ZA UPRAVLJANJE VOZNIM PARKOM}

Sustavi za upravljanje voznim parkom (engl. fleet management system, FMS) neizostavni su dio poslovanja suvremenih transportnih poduzeća jer pridonose povećanju učinkovitosti poslovanja i unaprjeđuju proces poslovnog odlučivanja. Njihovi temelji sežu u 1980-e godine kada su se računala ugrađivala u vozila i povezivala s raznim satelitskim i zemaljskim bežičnim mrežama (Fagerberg, 2017). lako je primjena sustava za upravljanje voznim parkom usmjerena na transportna i logistička poduzeća, ti se sustavi sve više koriste u raznim djelatnostima, npr. pomorskom prometu, trgovini, servisno-montažnim tvrtkama, komunalnim poduzećima, autoškolama, taksi i dostavnim službama, službama za spašavanje, građevinskim tvrtkama. Fleet management podrazumijeva cjelokupnu infrastrukturu i suvremena tehnološka rješenja koja omogućuju upravljanje flotom vozila u smislu automatizacije i optimizacije poslovnih procesa uz povezivanje svih segmenata poslovanja kao što su disponiranje, nabava, komunikacija, navigacija, računovodstvo i financije u jedinstven sustav koji je lako kontrolirati i optimizirati (VIDI, 2015).

Upravljanje voznim parkom podrazumijeva dio informacijskog sustava za potporu odlučivanju u poduzećima koji se bave prijevozom roba i ljudi (Grakalić i sur., 2013). Pod voznim parkom podrazumijeva se skup svih transportnih sredstava nekog transportnog poduzeća. Vozni park možemo nazvati i flota vozila. Flota predstavlja skupinu službenih i gospodarskih vozila. To mogu biti teretna i dostavna vozila, autobusi, zrakoplovi, taksiji, teretna motora vozila, tegljači, poluprikolice, prikolice. 
Slika 1. Elementi sustava za upravljanje voznim parkom

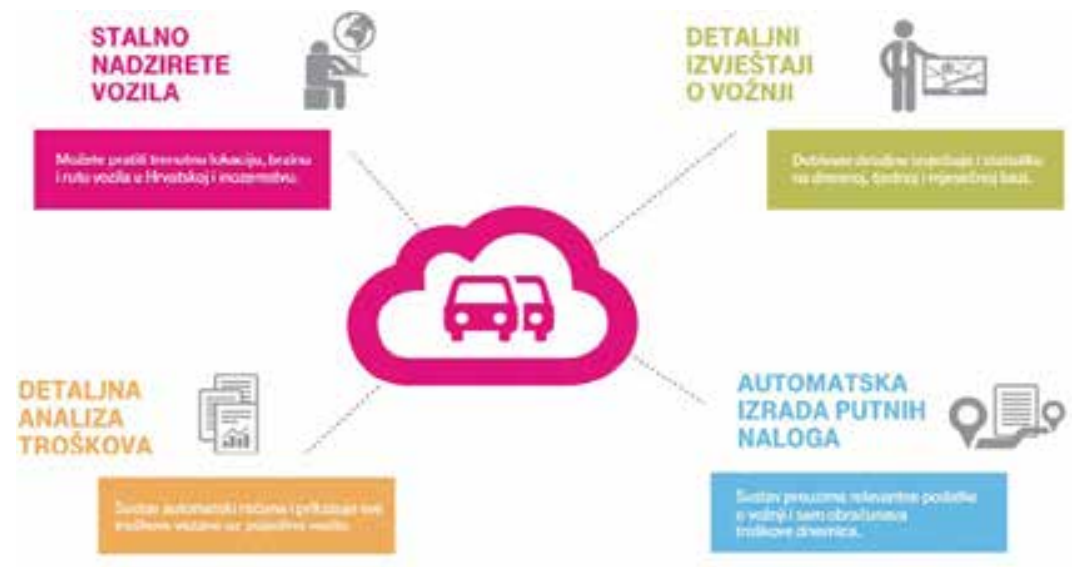

Izvor: http://www.poslovni.hr/tehnologija/sto-je-fleet-management-284832

Za upravljanje voznim parkom koriste se sustavi za navigaciju i praćenje vozila koji omogućuju određivanje položaja vozila, nadzor, bilježenje i optimizaciju putova. Primjenjuje se „cloud“ i tehnologija u realnom vremenu koja uz naprednu senzoriku omogućuje prosljeđivanje ključnih informacija o vozilu, stalni i potpuni nadzor voznog parka i neprekidnu komunikaciju s vozačem, udaljenu dijagnostiku te analizu načina vožnje vozača (https://mobilisis.hr). Sustavi za upravljanje voznim parkom koriste M2M (engl. machine to machine) način komunikacije gdje se razmjena podataka između dvaju uređaja odvija automatski, bez čovjekove intervencije, a podaci se šalju na centralnu lokaciju koristeći neku telekomunikacijsku mrežu (Grakalić i sur., 2013). Sve navedeno daje informacijsku podlogu za bolje planiranje i optimizaciju korištenja voznog parka i ruta, uštede goriva, cestarina i slično. Sustav za navođenje i praćenje vozila osim lociranja, nadgledanja i upravljanja vozilima omogućava i arhiviranje prikupljenih podataka u svrhu njihovog naknadnog pretraživanja, analize i stvaranja različitih vrsta izvještaja ovisno o potrebama poduzeća (slika 1).

\section{KOMPARATIVNA ANALIZA SUSTAVA ZA UPRAVLJANJE VOZNIM PARKOM}

Posljednjih godina broj tvrtki koje nude inteligentna rješenja za navigaciju i praćenje vozila u stalnom je porastu. Većina tih sustava zadovoljava potrebe svakog transportnog poduzeća. Razlike između sustava su u detaljima koje transportno poduzeće nakon godina korištenja sustava jednostavno prepoznaje. Sustavi nude sljedeće glavne usluge:

- praćenje i nadzor vozila u realnom vremenu

- identifikaciju vozača

- planiranje i upravljanje poslovnim procesima i troškovima

- komunikaciju između vozača i disponenta

- $\quad$ radne naloge (organizacija rada)

- putne naloge 
- alarmiranje

- izradu raznih izvještaja i statistika.

U nastavku će biti predstavljena tri sustava za upravljanje voznim parkom: Mobilisis, CVS Mobile i My GPS, te njihove mogućnosti. Sva tri sustava sastoje se od hardverskog i programskog dijela. Hardverski dio čine razni senzori na vozilima, sonde za gorivo, digitalni tahograf, uređaji za telekomunikaciju i bežični prijenos podataka, upravljačka jedinica, mobilni uređaji, terminali, računala i server. Kod sustava Mobilisis potrebno je kupiti svu navedenu opremu, a troškovi održavanja opreme su najveći, dok My GPS i CVS Mobile nude najam opreme i imaju niže troškove održavanja. Mogućnost najma opreme je bolje rješenje jer oprema brzo zastarijeva, a hardver nove generacije često nije kompatibilan s prethodnim.

\section{1 Sučelje aplikacija za upravljanje voznim parkom}

Sustav Mobilisis je hrvatski proizvod, a riječ je o inteligentnom sustavu za upravljanje, optimizaciju, nadzor i administraciju voznog parka (https://mobilisis.hr). Na početnom zaslonu prikazuje se karta sa svim vozilima pokrivenim navigacijskim sustavom (slika 2). Uz svako vozilo vezano je ime jednog vozača. Ako vozači koriste više vozila, opcija identifikacije vozača omogućava pravilno praćenje radnih sati vozača bez obzira kojim se vozilom služio, što je značajno prilikom obračuna plaće i dnevnica za vozače. Web-aplikacija prikazuje popis vozila (popis se može filtrirati prema sektoru, vrsti vozila, registraciji ili statusu), mjesto i smjer vozila na karti, podatke, obavijesti, poruke i ikone za različite poglede. Korisnik prema svojim potrebama određuje broj korisničkih računa u sustavu, te svakom korisničkom računu dodjeljuje pravo pristupa samo onim podacima koji su potrebni za obavljanje posla. Tako računovodstvo može vidjeti samo troškove i putne račune, a disponenti samo svoja vozila i putne radne listove. Ostali sustavi ne nude takvu mogućnost.

CVS Mobile (https://mobileweb.cvs-mobile.com/) ima jednostavno sučelje za prijavu korisnika kojemu se pristupa s Google Chrome preglednika (ispravno radi samo u tom pregledniku). Može zapamtiti prijavu korisnika tako da sljedeći put automatski ulazi u sustav (ostali to ne nude). CVS Mobile nudi prilagodbu izgleda sučelja tako da korisnik odabire razmještaj glavnih elemenata (pregled vozila, mjesto za poruke i kartu).

My GPS (http://www.ik-servis.com/) aplikaciji se pristupa preko internetskog preglednika. Nakon prijave korisnik bira prikaz kojim želi započeti rad, a najčešće je to praćenje vozila. Potom se otvara izbornik (karta ili tablica) te se izborom karte dobiva pregled kao i kod prethodnih sustava. Također je moguće napraviti razmještaj elemenata u prozoru aplikacije (mapa, popis vozila, poruke). 
Slika 2. Izgled početnog ekrana u aplikaciji Mobilisis

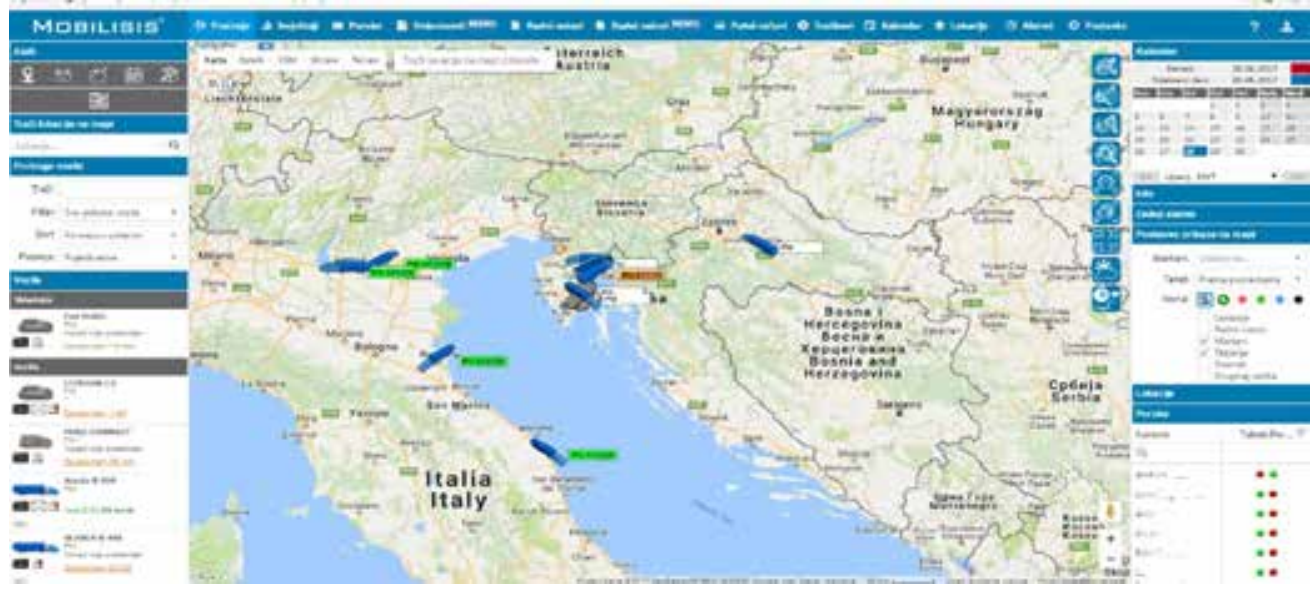

Izvor: rad autora

\section{2 Praćenje vozila}

Sustav Mobilisis (https://mobilisis.hr) omogućuje praćenje vozila na karti gdje se zelenom zastavicom označava početak rute, a crvenom ishodište (slika 3). Kružić na karti označava mjesta stajanja vozila. Na kružiću piše stop, a crvena boja pokazuje duljinu stajanja vozila na nekom mjestu. $\mathrm{Na}$ taj se način utvrđuje gdje su vozila dan prije završila putovanje i omogućava priprema planova za daljnje vožnje. Omogućeno je praćenje trenutne brzine vozila, vrijeme vožnje te obavijest je li vozilo zaustavljeno ili ne. Moguće je vidjeti sve rute za određeno vozilo i određeni dan, te za bilo koji datum provjeriti sva kretanja vozila. U slučaju da vozač nije siguran koju rutu izabrati može tražiti pomoć od disponenta (opcija „Traži lokaciju na mapi“ i prikaz optimalne rute) koji šalje potrebne informacije vozaču na navigaciju, čime se štedi vrijeme vozaču i izbjegava nepotrebno lutanje.

Slika 3. Praćenje vozila u aplikaciji Mobilisis

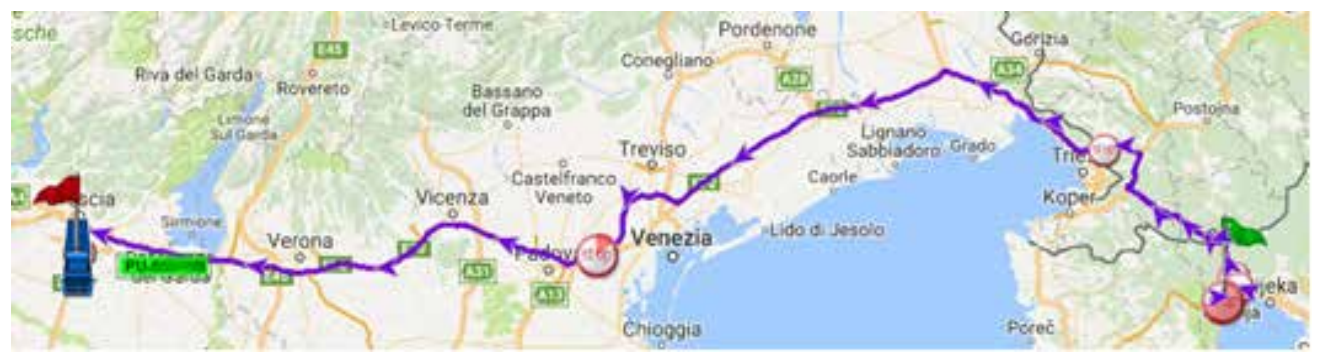

Izvor: rad autora

Na izborniku CVS Mobile aplikacije odabire se vozilo čija se ruta želi pratiti. Razlika u odnosu na Mobilisis je $u$ tome što vozač može sam upisati odredište $u$ navigaciju, a disponenti to vide na 
karti. Relacija koja je zadana ali nije izvršena označena je plavom bojom, što nemaju ostali sustavi, a korisno je (slika 4). Smeđom bojom je označen prijeđeni put. Oznakom P označena su stajanja, a uskličnikom mjesta gdje se upalio alarm, kao na slici 4 (alarm se uključio jer je vozač prekoračio dopuštenu brzinu). Da bismo pogledali rutu određenog dana u izborniku se izabere Izvještaj Analiza rada- Prevezene rute po vozilu ili vozaču. CVS Mobile ne daje prikaz na karti kao Mobilisis nego samo izvještaj u obliku teksta. Međutim, CVS Mobile je najbrži u pronalasku optimalne rute do odredišta, dok ostale aplikacije nude optimalne rute uz nešto više koraka (klikova).

Slika 4. Praćenje vozila u aplikaciji CVS Mobile

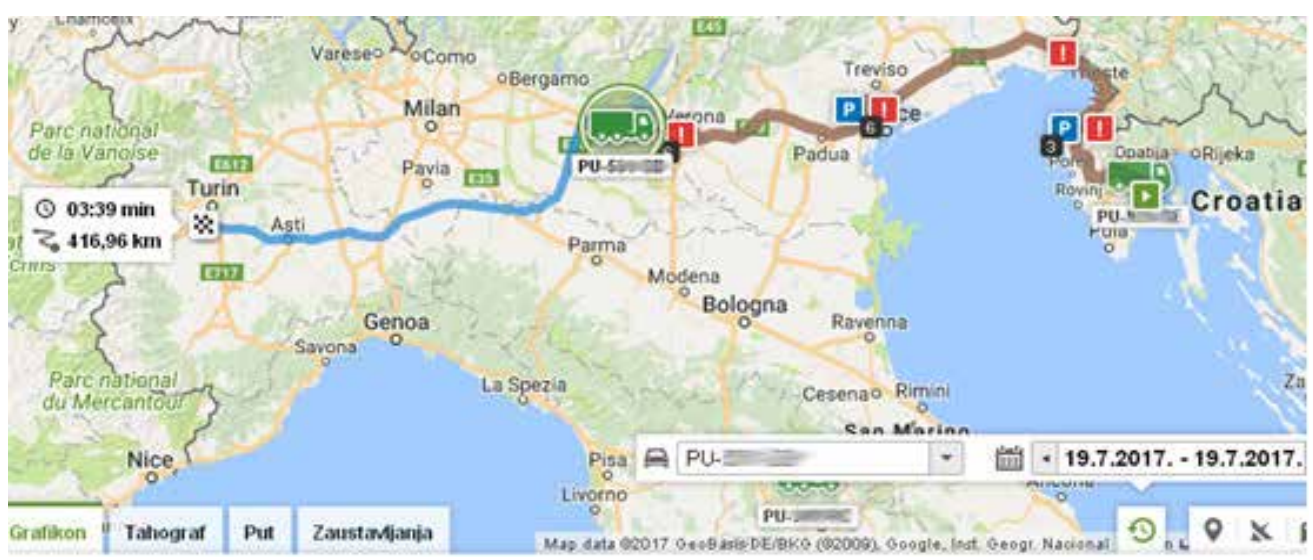

Izvor: rad autora

Da bi se vozilo u My GPS sustavu pratilo dnevno, prilikom uključivanja karte u izborniku se mora odabrati opcija "od ponoći". Tek tada se prikazuje ruta vozila za taj dan, kao na slici 5.

Slika 5. Praćenje vozila u aplikaciji My GPS

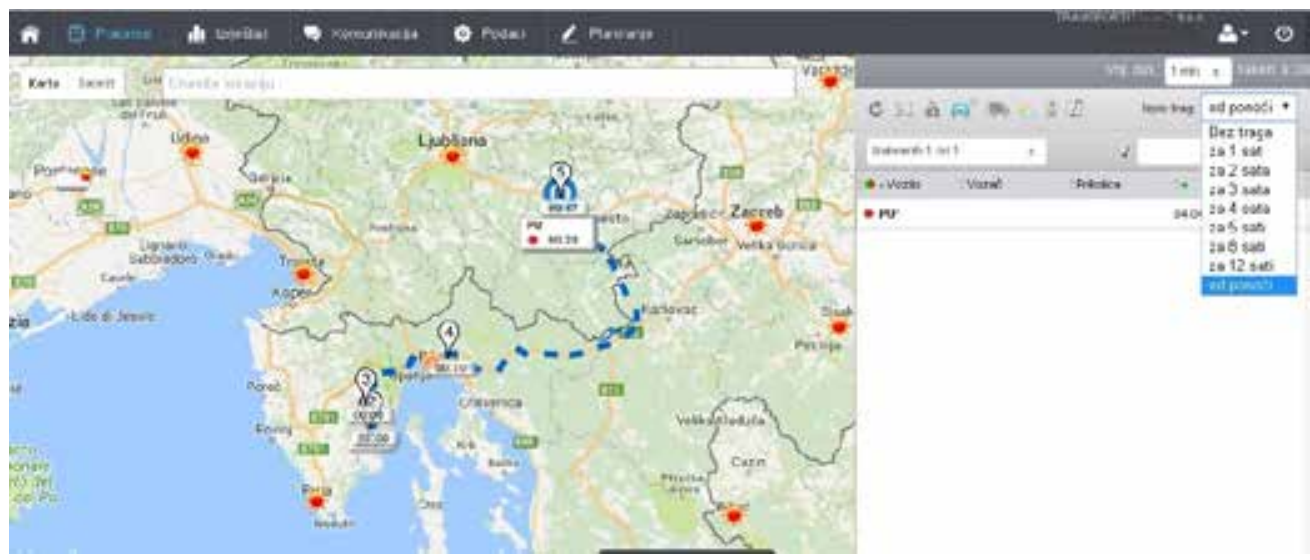

Izvor: rad autora 


\section{3 Izrada izvještaja}

Izvještaji i statistika u Mobilisisu pružaju razne podatke o vozilima (npr. je li motor ugašen ili upaljen, kilometraža koju je vozilo prešlo, bilo dnevno, tjedno ili mjesečno), informacije o učinjenim troškovima (ukupni troškovi vozila za određeni period), o gorivu (popis točenja, popis potrošnje na stajanju, je li se desila krađa goriva). Izvještaji o vozačima omogućuju uvid u „top 10 vozača“: tko je najviše vozio, najbrže vozio, najviše kilometara prošao, broj okretaja motora, kočenje, dodavanje gasa i sl. (gorivo, popravci, servisi), čime se vrlo lako dolazi do analize stila vožnje pojedinog vozača. Korekcijom stila vožnje može se povećati sigurnost u prometu te smanjiti troškovi vožnje. Alarmi šalju razna upozorenja. Prilikom izrade izvještaja može se odabrati jedno vozilo ili više njih, jedan vozač ili više njih, te vremenski period. Izvještaji se odnose na vozila, troškove, goriva, vozače. Najviše se koristi izvještaj rada vozila ili statistički podaci po vozaču (sortirano po datumu, uz pregled noćne vožnje). U tom izvještaju dobiju se dnevne i ukupne vrijednosti koje poduzeće zanimaju, a to su ukupno prijeđeni kilometri i sati vožnje po vozačima i vozilima. Ovaj se izvještaj prati na tjednoj bazi da bi se ustanovilo radno vrijeme mobilnih radnika. Pomoću njega se provjerava je li vozač u bilo kojem trenutku prekršio zakon o radnom vremenu (smije voziti 45 sati tjedno ili 90 sati dvotjedno).

CVS Mobile nudi mnoge vrste izvještaja kojima se analizira potrošnja goriva ili obavlja analiza načina vožnje, zaustavljanja, analiza senzora i slično. Rezultati tih analiza mogu se prikazati i u obliku Excelove tablice. Kod analize potrošnje goriva moguće je utvrditi pregled potrošnje po vozilu, usporediti vozila po potrošnji, utvrditi razinu goriva u vozilu i dobiti pregled točenja goriva po vozilima. Analiza rada pokazuje prevezene rute po vozilu i po vozaču, rute voznog parka, pregled korištenja vozila, evidenciju rada koja se odnosi na dnevni i noćni rad. Analiza načina vožnje otkriva stil vožnje te ukazuje na brigu ili nebrigu vozača za svoje sredstvo rada. Izvještaji se prate tako da se odabere vozilo i promatrani period. Moguće ih je promatrati na tri načina: FMS (prema podacima iz računala u kamionu), GPS (prema signalu teleoperatera) te MAP (prema izračunu Google Maps).

My GPS nudi izvještaje kao što su GPS, vozač, države, pregled vožnje, izvještaj poluprikolica i radno vrijeme. Za transportno poduzeće najzanimljiviji izvještaj je pregled vožnje i putni nalozi koji se nalaze u modulu podaci.

\subsection{Kontrola goriva}

Gorivo je značajna stavka u strukturi troškova svake tvrtke s voznim parkom i upravo zato zahtijeva poseban nadzor i kontrolu. Mobilisis nudi kvalitetno rješenje s ugradnjom mjerne sonde direktno u spremnik goriva vozila, a prema iskustvu transportnog poduzeća ostvaruju se uštede do $20 \%$. Nagla smanjenja razine goriva, bilo kakve nepravilnosti, razna točenja i istakanja bilježe se na listi goriva i prikazuju grafovi iz kojih se može jasno utvrditi vrijeme i mjesto događaja, kao i promjene u količini goriva (https://mobilisis.hr). Postoji i nedostatak ovog sustava, a odnosi se na sonde u spremnicima za gorivo koje su jako osjetljive, pa je umjesto dogovorenog i prihvatljivog odstupanja od 2 - $5 \%$ internim kontrolama u poduzeću utvrđeno nešto veće odstupanje. Da bi se dobio precizan obračun 
za odstupanje sonde, koristi se izvještaj Usporedba utočene količine goriva po računu i po sondi.

\section{5 Analiza troškova}

Vođenje evidencije o troškovima moguće je po vozilu, djelatniku, mjestu nastanka troška, tipu troška i sl. Cilj praćenja troškova je u racionaliziranju troškova, a da bi to bilo moguće, najprije se mora utvrditi što sve čini troškove poduzeća i gdje su oni najveći. Jedan klik dovoljan je da se sazna koje vozilo ima najveću potrošnju goriva, koji sektor radi najviše troškova ili koji su troškovi najzastupljeniji u strukturi troškova voznog parka. Navedeni podaci prikazuju se grafikonima koji vizualiziraju rezultate i daju podlogu za brzo djelovanje (slika 6).

\subsection{Radni nalozi}

Radne naloge u sustavu Mobilisis upisuje disponent tako da odabere vozilo, unese adresu utovara, istovara, nalogodavca i podatke o teretu. Upisuje se datum i vrijeme polaska, te datum i vrijeme dolaska, što je važno kada je za utovar ili istovar predviđen fiksni termin, a potom se kreira nalog. Vozač primi nalog, disponent povratno dobije automatsku poruku da je zaprimio nalog, vozač preuzima nalog i on se automatski učitava u njegovu navigaciju, te ga vodi na utovar ili istovar.

CVS Mobile i My GPS nemaju u svojoj ponudi kreiranje radnih naloga, već se nalozi šalju putem poruka unutar sustava. CVS Mobile nudi mogućnost pregleda arhive poruka, pa je u slučaju ponavljanja naloga dovoljno kopirati raniju poruku i proslijediti je dalje.

Slika 6. Grafički prikaz troškova u aplikaciji Mobilisis

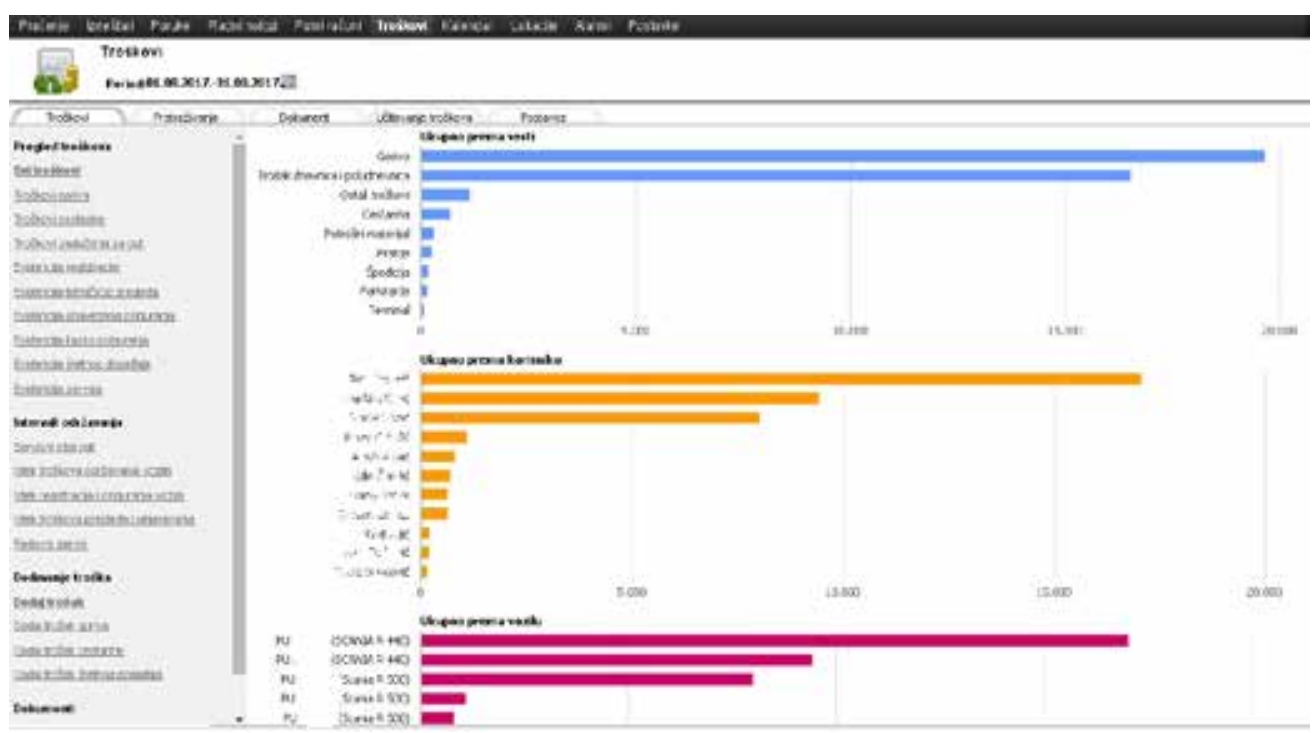

Izvor: rad autora 


\subsection{Putni nalozi}

Putni nalozi su veoma važna i zakonski propisana obveza u transportnom poduzeću. Temeljem putnog naloga vozačima se isplaćuje dnevnica za službeno putovanje. Stoga radno vrijeme vozača koji se premješta iz jedne države u drugu treba biti točno i precizno utvrđeno.

$\mathrm{Na}$ osnovi radnog naloga koji se kreira za vozače u sustavu Mobilisis, kreira se i putni nalog. $U$ prošlosti su se radni zadaci definirali kroz pojedinačne tiskane radne naloge koji su vozaču određivali rutu putovanja. Mana ovog sustava bila je nemogućnost praćenja rada vozača, praćenja koriste li ispravne rute, kojom brzinom voze i sl. Nedostatak kontrole dovodio je do kršenja radne discipline, zloupotrebe vozila i neekonomičnosti upotrebe vozila. (Grakalić i sur., 2013). Sustav Mobilisis uskladio je izgled i sadržaj putnog naloga s važećim zakonskim propisima. Na taj način se skraćuje vrijeme za obračun dnevnica, jer ručni unos oduzima puno vremena i postoji veća mogućnost pogrešaka, a ovako se putni nalog sam kreira.

Sustav CVS Mobile još uvijek nema razrađen modul za izradu putnih naloga. Jedini izvještaj koji sustav generira, a temeljem kojeg se mogu izraditi putni nalozi, je Prelasci granice po vozačima koji pokazuju točno vrijeme vožnje u pojedinoj državi.

U aplikaciji My GPS putni nalog kreira se na temelju relacija koje je vozilo imalo za određeni period, a sustav ne nudi mogućnost izrade radnog naloga. Putni nalozi u aplikaciji My GPS imaju sve zakonski predviđene elemente, uz jednostavan i precizan način izračuna dnevnica. Odabere se vozilo, vozač i datumi, tj. period za koji se radi putni nalog. Tako se dobiju sve relacije koje je vozač napravio, od mjesta utovara do istovara, te koliko je vremena boravio u određenoj državi. Izborom pojedinih etapa stvaraju se relacije, a izborom nekoliko relacija (u slučaju transportnog poduzeća od ponedjeljka do subote), izračunavaju se dnevnice. Nedostatak aplikacije My GPS je što ne prepoznaje pauzu koju vozilo mora napraviti zbog vikenda (nedjelju računa kao radni dan), pa je to potrebno ručno korigirati kod obračuna dnevnica.

\section{8 Komunikacija između vozača i disponenta}

Jako važan segment navigacije na terenu je komuniciranje porukama. Vozači na taj način javljaju statuse kao npr. iskrcano, ukrcano, traže informacije kada imaju problem koji ne mogu sami riješiti, javljaju točenja goriva, količinu ukrcanog tereta itd. Nova generacija opreme nudi mogućnost glasovne komunikacije pomoću tableta, iako disponenti sve naloge i obavijesti za vozače šalju porukama.

CVSMobile sustav također koristi glasovnu komunikaciju (vozači imaju tablete) te nudi mogućnost slanja poruke na mobitel. U slučaju da se vozač ne nalazi u kamionu ili je kamion ugašen, nakon određenog perioda vozač poruku dobiva na mobitel, što nemaju drugi sustavi. U Mobilisisu se komunicira porukama, iako je moguća i glasovna komunikacija putem tableta. U konkretnom transportnom poduzeću nije implementirana usluga glasovne komunikacije unutar sustava Mobilisis. 


\subsection{Mobilne verzije aplikacija}

Mobilisis sustav nema mobilnu verziju aplikacije, već se preko preglednika na mobilnom uređaju može pristupiti web-aplikaciji i prijaviti se korisničkim imenom i lozinkom. Tada se nudi skraćeni izbor u odnosu na desktop verziju iste aplikacije, može se pogledati lokacija vozila i statistika dana, tjedna ili mjeseca, a poruke vozačima moguće je slati samo pojedinačno.

CVS Mobile ima mobilnu aplikaciju za Android ili iOS platforme. Postoje dvije mobilne aplikacije: Mobile Map za praćenje vozila i Mobile Chat za komunikaciju.

Mobilna aplikacija My GPS trenutno je dostupna samo na slovenskom jeziku, pa je otežano njeno korištenje. Nudi popis vozila i njihov položaj na karti. Može se vidjeti samo trenutna lokacija vozila budući da nema pregleda povijesti vožnji. Komunikacija se odvija unutar iste aplikacije.

Prilikom komunikacije s vozačem disponentu je najvažnije da bude siguran je li vozač pročitao poruku, ako nije na nju odgovorio. Sva tri sustava nude rješenje koje obavještava da je poruka viđena i pročitana.

\section{PREDNOSTI IMPLEMENTIRANJA SUSTAVA ZA UPRAVLJANJE VOZNIM PARKOM U TRANSPORTNO PODUZEĆE}

Prema istraživanju Frost i Sullivan (2017) implementacija sustava za upravljanje voznim parkom donosi:

- povećanje produktivnosti 10 - $15 \%$

- smanjenje prekovremenih radnih sati $10-15 \%$

- smanjenje troškova goriva $20-25 \%$

- smanjenje ukupno prijeđenih kilometara 5 - $10 \%$

- povećanje korištenja vozila 15 - $20 \%$

- smanjenje vremena vozila u praznom hodu 20 - $30 \%$.

Najveća prednost implementiranja sustava za upravljanje voznim parkom u transportno poduzeće je što omogućuju pravovremeno detektiranje kritičnih točaka u poslovanju poduzeća i smanjenje troškova kao što su: troškovi praznog hoda, prosječna potrošnja goriva po vozilu, troškoviodržavanja vozila i osiguranja, broj radnih sati vozila i zaposlenika, broj prometnih nezgoda sa službenim vozilima, telefonski računi vozača u inozemstvu, papirologija. Korekcijom stila vožnje povećava se sigurnost u prometu i smanjuju troškovi vozila, produžuje im se vijek trajanja i indirektno smanjuju troškovi održavanja i servisa vozila. Uštede se ogledaju i u nižim troškovima cestarina zbog korištenja alternativnih pravaca. Najvažnija ušteda kod upotrebe sustava za upravljanje voznim parkom je u smanjenju potrošnje goriva i do $20 \%$, što je značajno, s obzirom na to da je cijena goriva najveći trošak u transportnom poduzeću. Jednostavna i brza izrada putnog naloga štedi vrijeme zaposlenih. Istodobno, primijećeno je povećanje brzine usluga, radne discipline, poslovne učinkovitosti, pouzdanosti i sigurnosti prijevoza te stupnja organiziranosti i točnosti (mobilno praćenje). Transportno poduzeće koje koristi sva tri promatrana sustava dobilo je novog klijenta 
s višemilijunskim godišnjim prometom zbog mogućnosti organiziranja posla prema zahtjevima klijenta, a tiču se praćenja sata utovara i istovara.

Dodatne funkcionalnosti koje ovakvi sustavi pružaju ogledaju se u pravodobnoj prevenciji nepredviđenih troškova i grešaka koje se mogu desiti vozačima na putovanjima, a koje je moguće ispraviti prije nego roba dođe na utovar ili istovar. Nadalje, takvi sustavi nude mogućnost daljinske blokade pokretanja motora putem SMS usluge, kao i daljinske blokade dovoda goriva, što je važno u slučaju krađe vozila.

Upoduzećima koja imaju hladnjače sustavi omogućuju mjerenje temperature pomoću postavljenih senzora. Na taj se način krajnji korisnik transportne usluge može uvjeriti da je u prostoru za hlađenje bila propisana temperatura tijekom cijelog trajanja prijevoza. Sustav upozorava na kritične promjene u temperaturi u slučaju nekog kvara te količinu goriva koju je potrošio agregat za hlađenje. U poduzećima koja su orijentirana na dostavu „vrata do vrata“ opisani sustavi omogućuju ispise dokumenata u vozilima (računi, ponude, primke, otpremnice i sl.), tj. nude mogućnost tzv. mobilnog ureda.

\section{ZAKLJUČAK}

Pravovremena dostupnost relevantnih informacija u poslovnom svijetu, gdje je vrijeme novac, neizmjerno je važna. Sustavi za upravljanje voznim parkom omogućuju nadzor i praćenje vozila u realnom vremenu, što rezultira optimizacijom poslovnih procesa transportnog poduzeća, smanjenjem troškova, a direktno utječe i na ljudske potencijale poduzeća u smislu povećanja radne discipline i poslovne učinkovitosti. Vozači radno vrijeme provode isključivo u okviru svojih radnih zadataka, pažljivije voze i odgovorno se ponašaju u vožnji. Sustav za upravljanje voznim parkom pomaže u proširenju poslovanja bez povećanja fiksnih troškova i broja zaposlenih. Trenutna dostupnost preciznih i detaljnih informacija o vozilu uz optimizaciju ruta omogućuje pružanje kvalitetnije usluge klijentima, što transportno poduzeće čini prepoznatljivim i konkurentnijim na tržištu. Iz svega dosad navedenog proizlazi da je investiranje u sustav za upravljanjem voznim parkom neophodno za transportno poduzeće jer pridonosi ostvarenju maksimalnog učinka (unaprjeđuje poslovanje, omogućuje pružanje bolje usluge klijentima i ostvarivanje konkurentske prednosti) uz smanjenje troškova transportnog poduzeća, čime se radna hipoteza prihvaća.

Sva tri analizirana sustava zadovoljavaju potrebe transportnog poduzeća, a značajno se razlikuju jedino u cijeni. Analizom triju sustava utvrđeno je da Mobilisis daje obuhvatno rješenje, ali i najskuplje. Zadovoljavajuće funkcionalnosti ima sustav My GPS po znatno nižoj cijeni, dok velik nedostatak sustava CVS Mobile leži u nemogućnosti izrade putnih naloga. Kao najvažniji kriteriji u procjeni uzeti su: mogućnost izrade putnih naloga i izračuna dnevnica, cijena sustava ijednostavnost uporabe. Dakle, moguće je odabrati skuplje ili jeftinije rješenje s vrlo sličnim funkcionalnostima. 


\section{LITERATURA}

CVS Mobile, http://www.cvs-mobile.hr (2. 9. 2017.)

Fagerberg, J. (2017) Fleet management in Europe, 12th Edition, M2M Research Series, Berg Insight, http://www. berginsight.com (18. 2. 2018)

Frost \& Sullivan (2017) Global Connected Truck Telematics Outlook, https://store.frost.com/global-connected-trucktelematics-outlook-2017.html (17.2. 2018)

Grakalić, I., Franušić, M., Štern, A. (2013) „Telekomunikacijski aspekti upravljanja flotom“, Zbornik Veleučilišta u Rijeci, Vol. 1 (2013.), No. 1, p. 279-289.

Mobilisis, https://mobilisis.hr_(2. 9. 2017.)

Mobilno praćenje, https://www.mobilnopracenje.com/prednosti (3. 1. 2018.)

My GPS, http://www.ik-servis.com/ (2. 9. 2017.)

Newman, P. (2016) „The Fleet Management Report: Examining how fleet operators are connecting their vehicles to better manage them", BI Intelligence, Business Insider, http://www.businessinsider.com/fleet-management-researchhow-operators-manage-and-connect-vehicles-2016-10 (16. 2. 2018.)

Statista (2016) Number of fleet management systems in active use in North America in 2015 and 2020, https://www. statista.com/statistics/261378/number-of-fleet-management-systems-in-use-in-north-america/ (15. 02. 2018)

VIDI (2015) „Fleet management: inteligentno upravljanje vozilima tvrtke“, VIDI.biz, br. 232, http://www.tbizcrunch.com/ index.php/vidi-biz/item/793-fleet-management-inteligentno-upravljanje-vozilima-tvrtke (5. 1. 2018.) 


$\begin{array}{lr}\text { Barbara Škabić } & \text { Professional paper } \\ \text { Elena Krelja Kurelović }^{2} & \text { UDC } 351.811 .123 \\ \text { Jasminka Tomljanović } & 656.223 .1\end{array}$

\title{
COMPARISON OF FLEET MANAGEMENT SYSTEMS ${ }^{4}$
}

\begin{abstract}
The use of the fleet management system significantly facilitates and improves the organization and business of modern transport companies. The fleet management system enables automation and business process optimization by linking all segments of business (disposition, procurement, communication, navigation, accounting and finances). They use modern technology solutions such as satellite navigation system, mobile technology, wireless communication and data transfer, cloud computing and telemetry (vehicle sensors, remote diagnostics devices). The fleet management system can determine the position of any vehicle in real time, make remote control of a vehicle and perform various measurements, record and optimize routes, monitor the driver's working hours, monitor costs (fuel and other), store the collected data for their search, analysis, and creating reports. The paper provides a comparative analysis of three fleet management systems (Mobilisis, CVS Mobile and My GPS) based on their real use in a transport company. The systems are analyzed and compared according to interface customization, vehicle tracking, reports, fuel consumption monitoring and cost control, work order and travel warrant, and by communication between drivers and disponent. It has been found out that Mobilisis provides the most comprehensive solution, although the most expensive one, while My GPS has all the necessary functionality at a much lower price, and a disadvantage of CVS Mobile is the inability to make travel warrants.
\end{abstract}

Keywords: fleet tracking, navigation, cost management, travel warrant, e-business

Bacc. oec., Transporti Runko d.o.o., Marišće 46b, Pićan, Croatia. E-mail: barbara.skabic@gmail.com

PhD, Senior Lecturer, Polytechnic of Rijeka, Vukovarska 58, 51000 Rijeka, Croatia. E-mail: elena@veleri.hr

Mr. sc., v. pred., Veleučilište u Rijeci, Vukovarska 58, 51000 Rijeka, Hrvatska. E-mail: jasminka.tomljanovic@veleri.hr

Received: 15 January 2018; Accepted: 1 March 2018 
